\title{
Nuclear characteristics of cardiac myocytes following the proliferative response to mincing of the myocardium in the adult newt, Notophthalmus viridescens
}

\author{
John O. Oberpriller ${ }^{1}$, Jean C. Oberpriller ${ }^{1}$, A.M. Arefyeva ${ }^{2}$, Victor I. Mitashov ${ }^{2}$, and Bruce M. Carlson ${ }^{3}$ \\ ${ }^{1}$ Department of Anatomy, University of North Dakota, Grand Forks, North Dakota, USA; \\ ${ }^{2}$ Institute of Developmental Biology, Academy of Sciences of the USSR, Moscow, USSR; \\ ${ }^{3}$ Departments of Anatomy and Biology, University of Michigan, Ann Arbor, Michigan, USA
}

Summary. Amphibian cardiac myocytes are predominantly mononucleated and have been demonstrated to respond to injury with DNA synthesis and mitosis. The nature of this response with regard to nuclear number and ploidy is unclear. In this study, the apex of the newt ventricle was minced and replaced, increasing the reactive area of the wound. At 45 days after mincing following multiple injections of tritiated thymidine $(2.5 \mu \mathrm{Ci} /$ animal, $20 \mathrm{Ci} / \mathrm{mM}) 15$ to 20 days after mincing, three ventricular zones were isolated and fixed: Zone 1, the minced area; Zone 2, extending approximately $500 \mu \mathrm{m}$ proximally from the amputation plane; and Zone 3, the portion proximal to Zone 2. Myocytes separated in $50 \% \mathrm{KOH}$ were examined for DNA synthesis by autoradiography and for nuclear number and DNA content using a scanning microdensitometer on Feulgen-Naphthol yellow S-stained cells. No labeled myocyte nuclei were found in control hearts and $98.3 \%$ of the myocytes were 2 C. At 45 days, $46.78 \%$ of myocyte nuclei within Zone 1 were labeled, while $13 \%$ were non-diploid. In Zone 2, 9.25\% were labeled with $4.8 \%$ non-diploid. In Zone $3,1.1 \%$ were labeled, with $2.8 \%$ non-diploid. The newt ventricle's response to injury apparently may involve complete mitosis and cytokinesis, resulting in mononucleated diploid cells.

Key words: Cardiac myocytes - Proliferation - Ploidy DNA synthesis - DNA content - Notophthalmus viridescens (Urodela)

The proliferative potential of adult myocytes has proven to differ among the 3 types of muscle tissue. In skeletal muscle, it appears that myocytes are incapable of cell division and that the tissue responds to stress or trauma by cell division of the satellite cell (Mauro 1979). The system consists of diploid cells (Lash et al. 1957). In contrast, adult mammalian smooth muscle myocytes can respond to tissue trauma by a partial loss of differentiated structure and by an activation of cell division (McGeachie 1971). Polyploidization has been demonstrated to occur in smooth muscle hypertrophy (Owens et al. 1981). In cardiac myocytes, the proliferative response which occurs as a result of injury or stress appears to be diverse, depending upon age and

Send offprint requests to: Dr. John Oberpriller, Department of Anatomy, University of North Dakota, School of Medicine, Grand Forks, North Dakota 58202, USA species (Rumyantsev 1977; Oberpriller and Oberpriller 1985).

In the human cardiac myocyte, nuclear polyploidization is known to occur normally in development between years 8 and 12, resulting in tetraploid cells (Adler et al. 1981). With hypertrophy, polyploidization is increased further (Sandritter and Scomazzoni 1964). In rat atria subjected to overload stress by coronary artery ligation, myocytes are able to undergo DNA synthesis and mitosis, which largely results in binucleation and, to a small extent, nuclear polyploidization (Rumyantsev and Mirakyan 1968; Rumyantsev and Kassem 1976; Oberpriller et al. 1983, 1984).

Unlike many mammalian systems, the amphibian heart is predominantly mononucleated (Tate et al. 1987) and is known to respond to damage by DNA synthesis and mitosis. The amphibian response to injury has been studied in both adult frog (Rumyantsev 1973, 1981) and adult newt cardiac myocytes (Oberpriller and Oberpriller 1985). In the adult newt ventricle, amputation of a portion of the ventricle results in DNA synthesis and mitosis in the myocytes immediately adjacent to the wound (Oberpriller and Oberpriller 1974). In an attempt to increase the reactive area of the wound, the amputated ventricular apex was minced and replaced onto the cut ventricular surface, resulting in a peak DNA synthesis with a labeling index of $24 \%$ and a mitotic index of $2.61 \%$ at 16 days after mincing (Bader and Oberpriller 1978, 1979). A major concern with this experimental system was whether or not the new cells were mononucleated and diploid as a result of cytokinesis. This seemed to be indicated by counts of the number of myocytes present in the mince at different times after mincing (Bader and Oberpriller 1979). However, because of the known diversity of response seen in other species, it was important to demonstrate the nature of the cell that resulted from the response to injury in this system, especially with regard to nuclear number and ploidy. Consequently, an investigation was undertaken in which myocytes taken from hearts which had been minced were examined for DNA synthesis, DNA content and nuclear number. Separated cells were used, enabling a more accurate assessment of these parameters than is possible in tissue section. This eliminates confusion with other cell types.

\section{Materials and methods}

Animals used in this study were adult newts, Notophthalmus viridescens, collected by Lee's Newt Farm in Tennessee. 

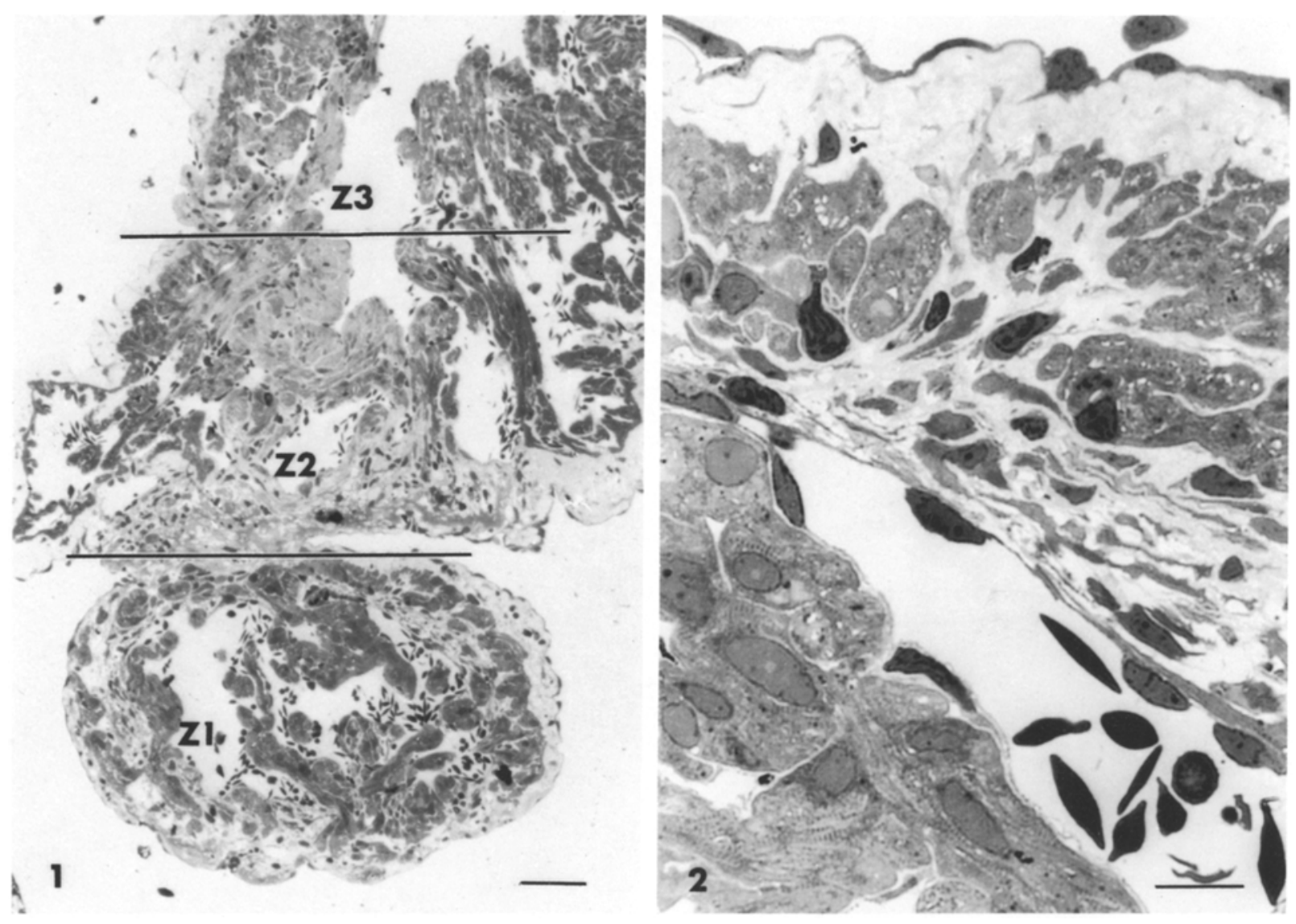

Fig. 1. Low power light micrograph showing ventricle fixed 45 days after mincing and replacing tip of ventricle. Ventricle was divided into 3 zones for fixation: Zone 1 (Z1), area of minced graft; Zone 2 (Z2), region approximately $500 \mu \mathrm{m}$ thick extending proximally from amputation plane; and Zone $3(Z 3)$, region proximal to Zone $2 . \times 79$. Bar $=100 \mu \mathrm{m}$

Fig. 2. Enlargement of area within Zone 1 of Fig. 1 in which is seen a number of myocytes containing myofibrillae. $\times 571$. Bar $=20 \mu \mathrm{m}$

They were maintained in plastic containers in aquarium water and fed liver once a week.

The newts used for experimentation were anesthetized in a 1:1000 solution of MS222. The ventral body wall and pericardium were cut with iridectomy scissors and oneeighth to one-fourth of the ventricular apex was removed, minced into pieces measuring 50 to $150 \mu \mathrm{m}$ and replaced as a sticky mass onto the amputation surface of the ventricle. Blood from the open ventricular chamber clotted rapidly and excess blood was removed using sterile gauze. The body wall was sutured and the animals were maintained as above, but were not fed until 20 days after surgery. The percentage of animals that survived the surgery was approximately $60 \%$.

From 15 to 20 days after mincing, the animals were given 5 intraperitoneal injections of $2.5 \mu \mathrm{Ci}$ tritiated thymidine (S.A. $=20 \mathrm{Ci} / \mathrm{mM}$; New England Nuclear). This period had been determined previously to be the peak labeling period for this system (Bader and Oberpriller 1978, 1979). Unoperated control animals were injected at the same time. Tissues were taken at 45 days after mincing and were fixed in either 3\% glutaraldehyde for light microscopy or in $10 \%$ neutral buffered formalin for cell separation. Control ventricles were fixed in their entirety. In the experimental ventricles, 3 zones were isolated and separately fixed (Fig. 1). The area of the mince was designated Zone 1. A region approximately $500 \mu \mathrm{m}$ thick extending proximally from and including the amputation plane was Zone 2 , which was known to include activated myocytes localized near the wound surface (Oberpriller et al. 1981). The region proximal to Zone 2 was Zone 3, which was known to be a zone containing few, if any, activated myocytes (Oberpriller et al. 1981).

Tissues were fixed in 3\% glutaraldehyde, buffered at $\mathrm{pH} 7.4$ with $0.1 \mathrm{M}$ phosphate buffer for $1 \mathrm{~h}$ and were postosmicated in Millonig's fixative for $1 \mathrm{~h}$. After dehydration in a graded series of ethanols, the tissues were embedded in a mixture of $1 / 2$ Araldite and $1 / 2$ Epon 812. Sections 1-2 $\mu \mathrm{m}$ in thickness were prepared for light microscopy and were stained with toluidine blue.

The cardiac tissue that had been fixed in $10 \%$ formalin was dissociated into single cells by immersion for $24 \mathrm{~h}$ in cold $\left(4^{\circ} \mathrm{C}\right) 50 \% \mathrm{KOH}$. The pieces of tissue were then rinsed for $4 \mathrm{~h}$ at room temperature in a large volume of distilled water. Thereafter the water was carefully decanted and the contents were stirred vigorously until a homogeneous cell suspension was obtained. The suspension was then diluted to the required cell density. Drops of the suspension were placed on glass microscope slides, dried and stained with a Feulgen-Naphthol yellow S method. The DNA content of the myocytes was measured on a Vickers M-86 scanning microdensitometer (Brodsky et al. 1985). For autoradiogra- 
phy, the slides were dipped in type " $\mathrm{N}$ " emulsion ("Photoplastinok" Factory, USSR) and exposed at $4^{\circ} \mathrm{C}$ for 18 days before developing.

Percentage values were determined for the number of myocytes of each Zone, which were labeled with tritiated thymidine and which had the ploidy levels of $2 \mathrm{C}, 2 \mathrm{C} \times 2$, $4 \mathrm{C}, 4 \mathrm{C} \times 2$, and $8 \mathrm{C}$. Comparisons with control unoperated ventricles were made using the Student $t$-test to determine the significance of the ploidy and labeling differences from the control values.

\section{Results}

No label was seen in the isolated myocytes from control (unoperated) hearts. As can be seen in Tables 1 and 2, $98.3 \%$ of the control cells were diploid and mononucleated, with a very small percentage of the myocytes being binucleated with diploid nuclei $(0.82 \%)$ or mononucleated with tetraploid nuclei $(0.89 \%)$.

The appearance of the experimental hearts at 45 days after mincing can be seen in Fig. 1, which indicates the 3 zones from which myocytes were isolated. The area taken as Zone 1 consists of the minced graft, Zone 2 is the adjacent reactive area and Zone 3 represents the non-injured portion of the heart. A higher power view of myocytes from a region of Zone 1 can be seen in Fig. 2. The myocytes of Zone 1 appear to be somewhat less organized and are surrounded by a greater amount of connective tissue than is seen in Zone 3 of Fig. 1.

In Table 1, ploidy levels and labeling indices are given for nuclei from myocytes of Zones 1, 2, and 3 from hearts having minced grafts and from control unoperated animals. In Table 2, labeled and unlabeled values are combined according to ploidy levels for the same groups.

It can be seen from Table 1 that $46.78 \%$ of the myocytes in Zone 1 were labeled. Most of the labeled cells were mononucleated and diploid, which represents $39.8 \%$ of the total cells in Zone 1. Zone 1 also included other labeled ploidy classes, such as $2 \mathrm{C} \times 2(1.97 \%), 4 \mathrm{C}(3.55 \%)$ and $4 \mathrm{C} \times 2(1.46 \%)$. Table 2 , which combines the labeled and unlabeled data, indicates that $13 \%$ of the myocytes in Zone 1 were non-diploid, as compared with only $1.71 \%$ found in controls. Of the myocytes examined in Zone 1, $5.99 \%$ were binucleated, including $4.3 \%$ with diploid nuclei and $1.7 \%$ with tetraploid nuclei. Also in Zone $1,7 \%$ were mononucleated and non-diploid, with $6.84 \%$ being tetraploid and a small percentage $(0.17 \%)$ being octaploid.

In Zone 2, which represents the activated area adjacent to the amputation site (Fig. 1), 9.25\% of the myocytes were labeled. Most of these were mononucleated and diploid, representing $8.2 \%$ of the Zone 2 myocytes. The other labeled ploidy classes included $2 \mathrm{C} \times 2(0.33 \%), 4 \mathrm{C}(0.62 \%)$, $4 \mathrm{C} \times 2(0.04 \%)$ and $8 \mathrm{C}(0.06 \%)$. Table 2 , which combines labeled and unlabeled data, indicates that $4.82 \%$ of the myocytes of Zone 2 were non-diploid, as compared with $1.71 \%$ found in controls. Also in Zone 2, 2.02\% were binucleated, including $1.94 \%$ with diploid nuclei and $0.08 \%$ with tetraploid nuclei. Of the myocytes examined in Zone 2 , $2.8 \%$ were mononucleated and non-diploid, including $2.64 \%$ which were tetraploid and $0.16 \%$ which were octaploid.

In Zone 3, which represents the area of the heart proximal to the adjacent reactive zone, a very low percentage $(1.1 \%)$ of labeled myocytes was observed. Most of the la-
Table 1. Ploidy levels of nuclei from myocytes from control (unoperated) and minced newt ventricles 45 days after mincing. Zones 1,2 , and 3 represent areas of ventricle progressively farther from wound, with Zone 1 being minced area, Zone 2 the adjacent reactive zone, and Zone 3 farthest from mince. Animals injected with tritiated thymidine from 15 to 20 days after mincing. Values given as percentages of total myocytes examined. With the exception of zero values, all percentages differ significantly from control values at the level of $p<0.001$

\begin{tabular}{llcll}
\hline & Control & Zone 1 & Zone 2 & Zone 3 \\
\hline $\begin{array}{l}\text { No. } \\
\text { myocytes }\end{array}$ & 3173 & 1545 & 2037 & 3864 \\
Animals & 3 & 3 & 3 & 4 \\
Unlabeled & & & & \\
2C & $98.30 \pm 0.64$ & $47.20 \pm 5.00$ & $87.00 \pm 7.90$ & $96.10 \pm 0.92$ \\
2C $\times 2$ & $0.82 \pm 0.65$ & $2.30 \pm 1.50$ & $1.60 \pm 0.56$ & $1.70 \pm 0.82$ \\
$4 \mathrm{C}$ & $0.89 \pm 0.08$ & $3.30 \pm 1.50$ & $2.00 \pm 0.52$ & $1.10 \pm 0.11$ \\
$4 \mathrm{C} \times 2$ & 0 & $0.26 \pm 0.08$ & $0.04 \pm 0.07$ & 0 \\
$8 \mathrm{C}$ & 0 & $0.17 \pm 0.17$ & $0.10 \pm 0.10$ & 0 \\
Labeled & & & & \\
2C & 0 & $39.80 \pm 2.60$ & $8.20 \pm 7.50$ & $0.96 \pm 1.00$ \\
2C $\times 2$ & 0 & $1.97 \pm 0.79$ & $0.33 \pm 0.16$ & $0.12 \pm 0.14$ \\
$4 \mathrm{C}$ & 0 & $3.55 \pm 3.77$ & $0.62 \pm 0.27$ & $0.02 \pm 0.04$ \\
$4 \mathrm{C} \times 2$ & 0 & $1.46 \pm 2.50$ & $0.04 \pm 0.07$ & 0 \\
$8 \mathrm{C}$ & 0 & 0 & $0.06 \pm 0.11$ & 0 \\
Total label & 0 & $46.78 \pm 2.0$ & $9.25 \pm 7.8$ & $1.1 \pm 1.2$ \\
\hline
\end{tabular}

Table 2. Summary of nuclear characteristics of myocytes taken from control (unoperated) and minced newt ventricles 45 days after mincing. Data consist of summary of Table 1 with combination of labeled and unlabeled values. Zones 1, 2, and 3 represent areas of ventricle progressively farther from wound. (See Table 1). Values given as a percentage of total myocytes examined. With the exception of zero values, all percentages differ significantly from control values at the level of $p<0.001$

\begin{tabular}{lcrlr}
\hline & Control & \multicolumn{1}{l}{ Zone 1 } & \multicolumn{1}{l}{ Zone 2 } & \multicolumn{1}{l}{ Zone 3 } \\
\hline $2 \mathrm{C}$ & $98.30 \pm 0.64$ & $87.27 \pm 4.86$ & $95.18 \pm 0.49$ & $97.16 \pm 0.75$ \\
$2 \mathrm{C} \times 2$ & $0.82 \pm 0.65$ & $4.30 \pm 2.35$ & $1.94 \pm 0.44$ & $1.76 \pm 0.74$ \\
$4 \mathrm{C}$ & $0.89 \pm 0.08$ & $6.84 \pm 5.11$ & $2.64 \pm 0.77$ & $1.08 \pm 0.13$ \\
$4 \mathrm{C} \times 2$ & 0 & $1.70 \pm 2.50$ & $0.08 \pm 0.13$ & \multicolumn{1}{l}{0} \\
$8 \mathrm{C}$ & 0 & $0.17 \pm 0.17$ & $0.16 \pm 0.19$ & \multicolumn{1}{l}{0} \\
$\begin{array}{l}\text { Totals } \\
\text { Bi- }\end{array}$ & $100 \%$ & $100 \%$ & $100 \%$ & $100 \%$ \\
$\begin{array}{l}\text { nucleation } \\
\begin{array}{l}\text { Non- } \\
\text { diploid }\end{array}\end{array}$ & $1.71 \pm 0.64 \pm 0.65$ & $5.99 \pm 1.23$ & $2.02 \pm 0.46$ & $1.77 \pm 0.74$ \\
$\begin{array}{l}\text { Mono- } \\
\text { nucleated, }\end{array}$ & $0.89 \pm 0.08$ & $7.00 \pm 5.22$ & $2.80 \pm 0.95$ & $1.08 \pm 0.13$ \\
non-diploid & & & & \\
\hline
\end{tabular}

beled myocytes were mononucleated and diploid, which amounted to $0.96 \%$ of the total myocytes of Zone 3 . Zone 3 also included labeled myocytes which were $2 \mathrm{C} \times 2(0.12 \%)$ and $4 \mathrm{C}(0.02 \%)$. Labeled myocytes with ploidy levels of $4 \mathrm{C} \times 2$ and $8 \mathrm{C}$ were not observed. From Table 2, it can be seen that $2.84 \%$ of myocytes in Zone 3 were non-diploid as compared with $1.71 \%$ found in controls. Of the myocytes 
examined in Zone 3, 1.77\% were binucleated with diploid nuclei and $1.08 \%$ were mononucleated and tetraploid.

\section{Discussion}

The results of this study indicate that the adult newt heart is composed of myocytes which are predominantly (98.3\%) diploid and mononucleated. Myocytes from control ventricles demonstrated virtually no DNA synthesis. Binucleation with diploid nuclei and mononucleation with tetraploid nuclei were seen to a minor degree. This differs significantly from many other ventricular systems, in which adult myocytes are frequently binucleated with diploid nuclei. In the adult rat and mouse, $80-85 \%$ of the myocytes are binucleated, with little nuclear polyploidy (Katzberg et al. 1977; Brodsky et al. 1980; Brodsky et al. 1985; Kasten et al. 1981). The same is true of the guinea pig, rabbit, and cat (Korecky et al. 1979). In the human, although some binucleation does occur (Korecky et al. 1979), a major characteristic is nuclear polyploidization, with most adult myocytes being tetraploid (Adler et al. 1981). This appears to be true of primates in general (Zak 1974).

In vivo there are relatively few experimental systems in which the cardiac myocyte can be stimulated to undergo cell division and mitosis. The amphibian heart appears to be the most reactive of all systems studied (Oberpriller and Oberpriller 1985). Earlier studies have described the localized DNA synthetic and mitotic response of the newt ventricular myocyte to amputation of a portion of the ventricle (Oberpriller and Oberpriller 1974). Mincing and replacement of the amputated piece of myocardium was found to be a way of increasing the wound area. A major regenerative response has been observed in this minced myocardium, including an increase in the number of reactive cells and the formation of a partial functional wall (Bader and Oberpriller 1978, 1979). This minced system is therefore a system which allows more intensive study of the DNA synthetic and mitotic response of the adult newt ventricular myocyte.

The minced ventricle system of the newt heart has been thought to involve cell division with cytokinesis, but this has only been determined by indirect methods. The production of new myocytes was indicated by counts, taken in tissue sections, of the number of myocytes during the various stages of re-formation of a new ventricular wall from minced pieces. At 5 days, the number of cells had dropped to $94 \%$ of the original, by 16 days they were at $21 \%$ and at 50 days they were increased to $60 \%$ (Bader and Oberpriller 1979).

In the experimental animals, Zone 1, which included the minced area, had a total of $46.78 \%$ of the cells labeled with tritiated thymidine, with most of these being mononucleated and diploid. This latter group of cells may be assumed to be a product of a complete mitotic event with cytokinesis, which followed the DNA synthetic period of labeling. However, there is evidence that some mitotic events were incomplete or that cytokinesis was absent, with a total of $13 \%$ of the myocytes being non-diploid. Since few of the myocytes in control ventricles were non-diploid, it appears that binucleation and polyploidization are important phenomena in the response to injury seen in the activated area of the minced tissue, although the system remains predominantly a diploid mononucleated one after the proliferative response to injury. The high incidence of DNA synthesis in conjunction with a low rate of binuclea- tion and nuclear polyploidy in myocytes isolated from this activated system, is strong evidence for mitosis with cytokinesis in this system.

Zone 2, which is immediately adjacent to the minced zone, reflects the reaction seen in Zone 1, but at a lesser intensity. The percentage of labeled cells in Zone 2 correlates well with the percentages previously reported for the labeling index in the reactive region next to the amputation site when the apex of the newt ventricle was amputated and removed (Oberpriller and Oberpriller 1974). Zone 3, the area of the ventricle farthest from the minced apex, shows virtually no activation, with a total of $1.1 \%$ of the cells being labeled, and most of them being mononucleated and diploid. The minor activation changes seen in Zone 3 and those seen in Zone 2 reflect the basic diploid nature of the activated cardiac myocyte, implying that this system is one that produces cardiac myocytes capable of completing the mitotic process through cytokinesis.

The response of newt myocytes to injury is quite unique among the various species that have been studied. It is thought that most adult mammalian ventricular myocytes do not respond to injury or stress with any type of nuclear division (Oparil 1985). DNA synthesis of myocytes has been demonstrated in hypertrophied ventricles of weanling or neonatal animals after aortic constriction (Bishop 1973; Bugaisky and Zak 1979; Dowell and McManus 1978) and in nutritional anemia (Neffgen and Korecky 1972). However, the rat atrial myocyte can undergo DNA synthesis and mitosis in response to the overload stress caused by coronary artery ligation (Rumyantsev and Kassem 1976; Rumyantsev and Mirakyan 1968; Oberpriller et al. 1983, 1984; Oberpriller et al. 1985). This results largely in binucleation which indicates that mitosis occurred without completing cytokinesis. Nuclear polyploidization also occurs to a smaller extent after coronary artery ligation, with $10 \%$ of the myocytes exhibiting nuclear polyploidy. In the human, the cardiac myocyte nucleus is polyploid and can increase its ploidy class up to $64 \mathrm{C}$ during hypertrophy of the heart (Sandritter and Scomazzoni 1964). This seems to correlate with heart weight, and not with age (Adler and Friedburg 1986).

It is not known why the newt ventricle reacts with a process of complete mitosis and cytokinesis, while mammalian systems react predominantly with incomplete mitotic events resulting in binucleation and nuclear polyploidization. It has been suggested that binucleation and polyploidization may be the most efficient way for the hypertrophied cells of the mammalian system to increase mass while maintaining the tissue architecture (Brodsky and Uryvaeva 1977, 1985). In the case of the newt ventricle, the tissue of the mince and the tissue adjacent to an amputation have been severely traumatized, and tissue remodeling must occur, which appears to involve the production of new myocytes by cell division with cytokinesis.

Characterization studies of enzymatically separated newt myocytes indicate that the morphology of these myocytes differs considerably from that of mammalian myocytes (Tate et al. 1987). Newt myocytes are more fusiform, with several branching arms and a lack of T-tubules. Mammalian myocytes are more of an elongated rectangle with a well-developed T-tubule system (Dow et al. 1981). Because of these differences in the architecture of the cells themselves, these two types of myocytes may behave differently when encountering injury or stress. 
Characterization of myocytes in culture may lead to some understanding of the nature of the diversity of the myocyte proliferative response. DNA synthesis and multinucleation have been observed in the cultured ventricular myocyte of the adult rat (Claycomb and Bradshaw 1983; $\mathrm{Nag}$ et al. 1983). Although mitosis has not been demonstrated in these cells, a reactivation of DNA polymerase and thymidine kinase and semiconservative replication of DNA have been demonstrated. Mitosis has been demonstrated in the cultured atrial myocyte of the rat (Cantin et al. 1981). DNA synthesis and mitosis have also been observed in cultures of adult newt ventricular myocytes (Tate and Oberpriller 1987). However, cytokinesis has not yet been demonstrated in any of these systems. Many of the cells in such cultures become binucleated and multinucleated, perhaps as a result of cytokinesis being inhibited, either normally or because of the flattened morphological condition of the cells in culture. DNA content of these cultured cells has not yet been determined.

These experimental results emphasize the uniqueness of the amphibian system in its ability to undergo cytokinesis in its proliferative response to injury. This capability is common to the processes that occur in the ontogeny of cardiac muscle. An understanding of mechanisms involved in cell division of cardiac myocytes stimulated by injury or stress is needed. Future studies will be directed at attempts to determine why cells may form daughter cells or alternatively become binucleated or exhibit nuclear polyploidization as a result of partial cell division events.

Acknowledgments. This work was supported in part by NIH Grant DE 07687 (B.M.C.), by NSF Grant RII8610675 to the State of North Dakota (J.O.O.), and by research funds provided by the North Dakota Medical Education and Research Foundation (J.C.O).

\section{References}

Adler CP, Friedburg H (1986) Myocardial DNA content, ploidy level and cell number in geriatric hearts: Postmortem examinations of human myocardium in old age. $\mathrm{J}$ Mol Cell Cardiol $18: 39-53$

Adler CP, Ringlage WP, Bohm N (1981) DNS-Gehalt und Zellzahl in Herz und Leber von Kindern. Pathol Res Pract 172:25 41

Bader D, Oberpriller JO (1978) Repair and reorganization of minced cardiac muscle in the adult newt (Notophthalmus viridescens). J Morphol 155:349-358

Bader D, Oberpriller JO (1979) Autoradiographic and electron microscopic studies of minced cardiac muscle regeneration in the adult newt Notophthalmus viridescens. J Exp Zool 208:177-194

Bishop SP (1973) Effect of aortic stenosis on myocardial cell growth, hyperplasia and ultrastructure in neonatal dogs. Rec Adv Stud Card Struct Metab 3:637-656

Brodsky Y, Uryvaeva IV (1977) Cell polyploidy: its relation to tissue growth and function. Int Rev Cytol 50:275-332

Brodsky Y, Uryvaeva IV (1985) Genome multiplication in growth and development. Biology of polyploid and polytene cells. Cambridge University Press, Cambridge

Brodsky Y, Arefyeva AM, Uryvaeva IV (1980) Mitotic polyploidization of mouse heart myocytes during the first postnatal week. Cell Tissue Res 210:133-144

Brodsky Y, Tsirekidze NN, Arefyeva AM (1985) Mitotic-cyclic and cycle-independent growth of cardiomyocytes. J Mol Cell Cardiol 17:445-455

Bugaisky L, Zak R (1979) Cellular growth of cardiac muscle after birth. Tex Rep Biol Med 39:123-135
Cantin M, Ballak M, Beuzeron-Mangina J, Anand-Srivastava MB, Tautu C (1981) DNA synthesis in cultured adult cardiocytes. Science 214:569-570

Claycomb W, Bradshaw H (1983) Acquisition of multiple nuclei and the activity of DNA polymerase- $\alpha$ and reinitiation of DNA replication in terminally differentiated adult cardiac muscle cells in culture. Dev Biol 99:331-337

Dow JW, Harding NGL, Powell T (1981) Isolated cardiac myocytes. I. Preparation of adult myocytes and their homology with the intact tissue. Cardiovasc Res 15:483-514

Dowell RT, McManus RE (1978) Pressure induced cardiac enlargement in neonatal and adult rats: Left ventricular functional characteristics and evidence of cardiac cell proliferation in the neonate. Circ Res 42:303-310

Kasten F, Kudriavtsev B, Rumyantsev P (1981) Fluorescent Feulgen-DNA content of isolated cardiac myocytes (Abstract). J Histochem Cytochem 29:886

Katzberg AL, Farmer BA, Harris R (1977) The predominance of binucleation in isolated rat heart myocytes. Am J Anat $149: 489-500$

Korecky B, Sweet S, Rakusan K (1979) Number of nuclei in mammalian cardiac myocytes. Can J Physiol Pharmacol 57:1122-1129

Lash JW, Holtzer H, Swift H (1957) Regeneration of mature skeletal muscle. Anat Rec 128:679-698

Mauro A (1979) Muscle regeneration. Raven Press, New York

McGeachie JK (1971) Ultrastructural specificity in regenerating smooth muscle. Experientia 27:436

Nag A, Cheng M, Fischman D, Zak R (1983) Long-term cell culture of adult mammalian cardiac myocytes. Electron microscopic and immunofluorescent analysis of myofibrillar structure. J Mol Cell Cardiol 15:301-317

Neffgen JF, Korecky B (1972) Cellular hyperplasia and hypertrophy in cardiomegalies induced by anemia in young and adult rats. Circ Res 30:104-113

Oberpriller JO, Oberpriller JC (1974) Response of the adult newt ventricle to injury. J Exp Zool 187:249-259

Oberpriller JO, Oberpriller JC (1985) Cell division in cardiac myocytes. In: Ferrans VJ, Rosenquist GC, Weinstein C (eds) Cardiac morphogenesis. Elsevier, New York, pp 12-22

Oberpriller JO, Oberpriller JC, Bader DM, McDonnell TJ (1981) Cardiac muscle and its potential for regeneration in the adult newt heart. In: Becker RO (ed) Mechanisms of growth control. Charles C. Thomas, Springfield IL, pp 343-372

Oberpriller JO, Ferrans VJ, Carroll RJ (1983) Changes in DNA content, number of nuclei and cellular dimensions of young rat atrial myocytes in response to left coronary artery ligation. J Mol Cell Cardiol 15:31-42

Oberpriller JO, Ferrans VJ, Carroll RJ (1984) DNA synthesis in rat atrial myocytes as a response to left ventricular infarction. An autoradiographic study of enzymatically dissociated myocytes. J Mol Cell Cardiol 16:1119-1126

Oberpriller JO, Ferrans VJ, McDonnell TJ, Oberpriller JC (1985) Activation of DNA synthesis and mitotic events in atrial myocytes following atrial and ventricular injury. In: Stone $\mathrm{HL}$, Weglicki WB (eds) Pathobiology of cardiovascular injury. Martin Nijhoff Publishing, Boston, pp 410-421

Oparil S (1985) Pathogenesis of ventricular hypertrophy. J Am Coll Cardiol 5:57B-65B

Owens GK, Rabinovitch PS, Schwartz SM (1981) Smooth muscle cell hypertrophy versus hyperplasia in hypertension. Proc Natl Acad Sci USA 78:7759-7763

Rumyantsev PP (1973) Post-injury DNA synthesis, mitosis, and ultrastructural reorganization of adult frog cardiac myocytes. An electron microscopic autoradiographic study. Z Zellforsch $139: 431-450$

Rumyantsev PP (1977) Interrelations of the proliferation and differentiation processes during cardiac myogenesis and regeneration. Int Rev Cytol $51: 187-273$

Rumyantsev PP (1981) New comparative aspects of myocardial regeneration with special reference to cardiomyocyte prolifera- 
tive behavior. In: Becker RO (ed) Mechanisms of growth control. Charles C. Thomas, Springfield IL, pp 311-342

Rumyantsev PP, Kassem AM (1976) Cumulative indices of DNA synthesizing myocytes in different compartments of the working myocardium and conductive system of the rats heart muscle following extensive left ventricular infarction. Virchows Arch (Cell Pathol) 20:329-342

Rumyantsev PP, Mirakyan VO (1968) Increased activity of DNA synthesis and mitoses in rat atrial muscle cells under ventricular myocard infarction and local injuries of auricles. Tsitologiia $10: 1276-1286$

Sandritter W, Scomazzoni G (1964) Deoxyribonucleic acid content (Feulgen photometry) and dry weight (interference microscopy) of normal and hypertrophic heart muscle fibres. Nature 202:100-101
Tate JM, Oberpriller JO (1987) A light microscopic autoradiographic study of adult newt myocytes in cell culture. Anat Rec 218:135A-136A

Tate JM, McDonnell TJ, Oberpriller JC, Oberpriller JO (1987) Isolation of cardiac myocytes from the adult newt, Notophthalmus viridescens. An electron microscopic and quantitative light microscopic analysis. Tissue Cell 19:577-585

Zak R (1974) Development and proliferative capacity of cardiac muscle cells. Circ Res (Suppl II) 35:17-26 